\title{
Availability of Works Cited in Recent Law Review Articles on LEXIS, Westlaw, the Internet, and Other Databases
}

Simon Canick

Mitchell Hamline School of Law, simon.canick@mitchellhamline.edu

Publication Information

21 Legal References Services Quarterly No. 2/3 (2002)

\section{Repository Citation}

Canick, Simon, "Availability of Works Cited in Recent Law Review Articles on LEXIS, Westlaw, the Internet, and Other Databases" (2002). Faculty Scholarship. Paper 123.

http://open.mitchellhamline.edu/facsch/123 


\title{
Availability of Works Cited in Recent Law Review Articles on LEXIS, Westlaw, the Internet, and Other Databases
}

\begin{abstract}
In this study, a group of recent law articles was examined to determine the proportion of cited resources that are easily findeable online. Searches were conducted in databases such as LEXIS and Westlaw, and on the Internet, for full-text versions of every source cited in seven articles. The results have been broken down into 13 categories, including: federal cases, books, foreign law, and legal periodicals pre-1990. Not surprisingly coverage differs widely between the categories. Overall the study found that $77 \%$ of the 1,984 citations in the articles reviewed are available online. This article concludes with a general discussion of why the percentage is likely to increase in the future.
\end{abstract}

\section{Keywords}

Footnotes, LEXIS, Westlaw, citations, fulltext, law review articles

\section{Disciplines}

Legal Education | Legal Writing and Research 


\title{
Availability of Works \\ Cited in Recent Law Review Articles on LEXIS, Westlaw, the Internet, and Other Databases
}

\author{
Simon Canick
}

\begin{abstract}
SUMMARY. In this study, a group of recent law articles was examined to determine the proportion of cited resources that are easily findable online. Searches were conducted in databases such as LEXIS and Westlaw, and on the Internet, for full-text versions of every source cited in seven articles. The results have been broken down into 13 categories, including "federal cases," "books," "foreign law," and "legal periodicals pre-1990." Not surprisingly, coverage differs widely between the categories. Overall, the study found that $77 \%$ of the 1,984 citations in the articles reviewed are available online. The article concludes with a general discussion of why the percentage is likely to increase in the future. [Article copies available for a fee from The Haworth Document Delivery Service: 1-800-HAWORTH. E-mail address: $<$ getinfo@haworthpressinc.com> Website: <http://www.HaworthPress.com> (C) 2002 by The Haworth Press, Inc. All rights reserved.]
\end{abstract}

KEYWORDS. Footnotes, LEXIS, Westlaw, citations, fulltext, law review articles

Simon Canick is Reference Librarian, Arthur W. Diamond Law Library, Columbia University.

[Haworth co-indexing entry note]: "Availability of Works Cited in Recent Law Review Articles on LEXIS, Westlaw, the Internet, and Other Databases." Canick, Simon. Co-published simultaneously in Legal Reference Services Quarterly (The Haworth Information Press, an imprint of The Haworth Press, Inc.) Vol. 21, No. 2/3, 2002, pp. 55-67; and: Law Library Collection Development in the Digital Age (ed: Michael Chiorazzi, and Gordon Russell) The Haworth Information Press, an imprint of The Haworth Press, Inc., 2002, pp. 55-67. Single or multiple copies of this article are available for a fee from The Haworth Document Delivery Service [1-800-HAWORTH, 9:00 a.m. - 5:00 p.m. (EST). E-mail address: getinfo@ haworthpressinc.com].

(C) 2002 by The Haworth Press, Inc. All rights reserved. 


\section{INTRODUCTION}

In recent years, online resources have become compelling alternatives to traditional, print-based legal research for many attorneys and law students. This trend will surely continue as LEXIS, Westlaw, and the Internet broaden their coverage and become more reliable. So far, databases and Web sites have featured commonly used materials like statutes and case law. The wide availability of primary legal information and practice materials may lead some attorneys to believe that they no longer need to visit law libraries.

Legal scholarship is fundamentally different, however. Work produced by law school faculty and students, for instance, often relies upon obscure or historical sources that are available only in print. For Westlaw and LEXIS to keep scholars out of libraries, they will have to aggressively expand their coverage.

The purpose of this study was to assess the scope of various online databases with respect to a particular type of research. Specifically, a group of recent law review articles was examined to determine the proportion of cited resources that are easily findable online. Searches were conducted in several databases and on the Internet for full-text versions of every source cited in seven articles. The selection of the seven articles was arbitrary; no effort was made to ensure consideration of particular subjects, authors, or journals.

In the future, we may read online law review articles with direct links to the full text of each of the works to which they cite. It may be many years before this vision is achieved, however. This study found that a more modest, but still substantial $77 \%$ of the 1,984 citations in the articles reviewed are available online.

\section{METHODOLOGY}

For this study, seven recent law review articles were selected at random:

- Stephen R. Barnett, “The Right to One's Own Image”: Publicity and Privacy Rights in the United States and Spain, 47 Am. J. Comp. L. 555 (1999).

- John T. Boese \& Beth C. McClain, Why Thompson is Wrong: Misuse of the False Claims Act to Enforce the Anti-Kickback Act, 51 Ala. L. Rev. 1 (1999).

- William W. Bratton \& Joseph A. McCahery, Comparative Corporate Governance and the Theory of the Firm: The Case Against Global Cross Reference, 38 Colum. J. Transnat'1 L. 213 (1999). 
- John C. Coffee, Jr., Class Action Accountability: Reconciling Exit, Voice, and Loyalty in Representative Litigation, 100 Colum. L. Rev. 370 (2000).

- Andrew L. Kaufman, Benjamin Cardozo as Paradigmatic Tort Lawmaker, 49 DePaul L. Rev. 281 (1999).

- Joseph P. Monteleone \& Emy P. Grotell, Coverage for Employment Practices Liability Under Various Policies: Commercial General Liability, Homeowners', Umbrella, Workers' Compensation, and Directors' and Officers' Liability Policies, 21 W. New Eng. L. Rev. 249 (1999).

- Laurence C. Nolan, "Unwed Children" and Their Parents Before the United States Supreme Court From Levy to Michael H.: Unlikely Participants in Constitutional Jurisprudence, 28 Cap. U.L. Rev. 1 (1999).

These articles had little in common. Their subject areas ranged from the Civil False Claims Act, to Spanish publicity rights, to class action lawsuits, to the treatment of children born out of wedlock. As expected, this diverse body of articles included citations to a wide variety of resources, including cases, statutes, periodicals, working papers, treatises, government documents, and foreign law.

Each citation was coded according to its type. The following categories were created:

- Legal Periodicals 1990-present: Including law review articles, legal newspapers, and bar journals.

- Legal Periodicals pre-1990: Including law review articles, legal newspapers, and bar journals.

- Non-Legal Periodicals 1990-present: Including newspapers, magazines, and journals from other fields.

- Non-Legal Periodicals pre-1900: Including newspapers, magazines, and journals from other fields.

- Books: Including legal and non-legal treatises and looseleaf services.

- Reports/Working Papers: Including studies and reports issued by think-tanks, non-profit organizations, university groups, and governmental/quasi-governmental bodies.

- Federal Cases: All years, all court levels.

- State Cases: All years, all court levels.

- Federal Law: Including statutes and administrative material.

- State Law: Including statutes and administrative material. 
- Uniform Laws: Including Uniform Codes, Model Codes, and Restatements.

- Foreign/International Law: Including primary material, and government reports.

- Court Filings/Transcripts: Including pleadings and trial transcripts.

For each footnote, it was determined whether the cited material could be found using LEXIS or Westlaw. If unavailable there, other databases (e.g., JSTOR, ABI-INFORM, etc.) or the World Wide Web were consulted. If full-text could not be located in any online format, then that fact was noted.

Every citation in every article was counted, whether or not the resources encountered had been previously cited. This series of footnotes should illustrate the methodology employed:

73. See Orsini v. Blasi, 423 U.S. 1042 (1976).

74. 42 U.S.C. $\$ 512(b)(1994)$.

75. See id. § 512(a)-(c).

76. See, e.g., Douglas W. Diamond, Financial Intermediation and Delegated Monitoring, 51 Rev. Econ. Stud. 393 (1984).

If confronted with this list, LEXIS or Westlaw would first be checked to make sure Orsini was available there. If so, the case would be coded as found on Westlaw/LEXIS without inquiring whether, for example, the case existed on the Web. The same process would be followed for the two United States Code citations. ${ }^{1}$ For the journal article, Westlaw or LEXIS would be checked first. If unavailable there, other databases would be consulted. In this case, the article was found on JSTOR, so it was unnecessary to inquire whether a Web site had its text as well.

\section{GENERAL FINDINGS}

As previously noted, $77 \%$ of the works cited were found online. LEXIS and Westlaw have the broadest coverage, providing access to $73 \%$. Roughly $4 \%$ (79 out of 1,984 total citations) could be found only on another database or the Internet.

The percentage of citations available online varied widely from article to article. For instance, $98 \%$ of the cited works from Monteleone and Grotell were found, compared to only $48 \%$ from Bratton and McCahery. The difference lies in the types of material most frequently footnoted. Monteleone and Grotell relied heavily on case-law, while Bratton and McCahery routinely cited relatively hard-to-find items, like books and non-legal periodicals. 


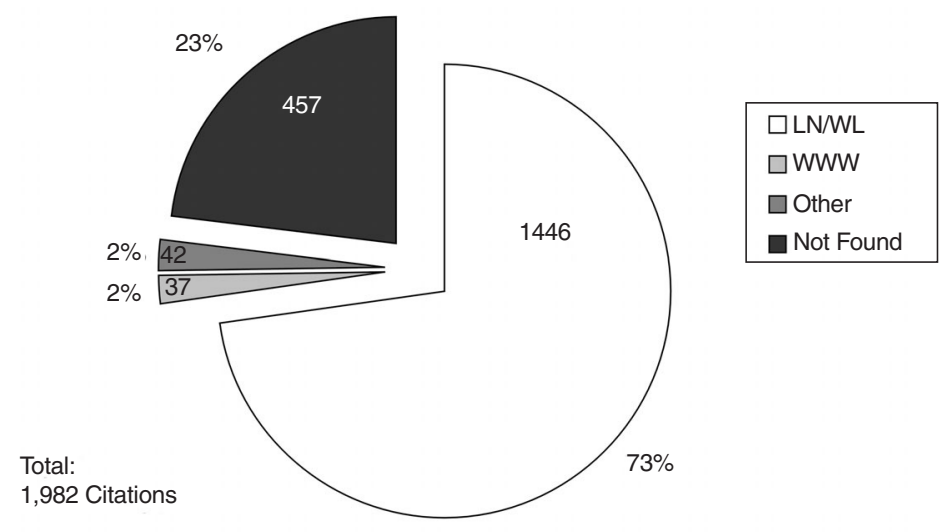

\section{SPECIFIC FINDINGS}

- Legal Periodicals 1990-Present: Of 163 citations to recent legal periodicals, 150 (92\%) were found on LEXIS or Westlaw. The remaining 13 were unavailable in any online source.

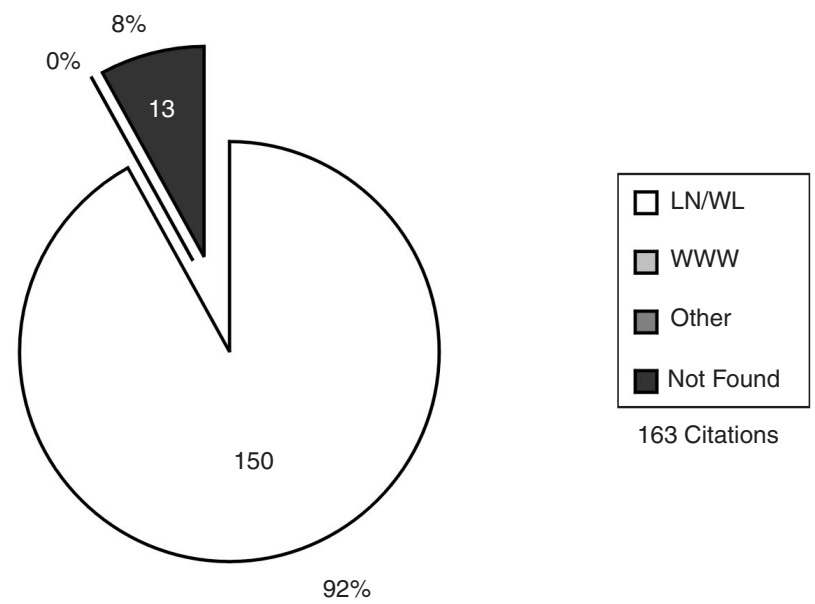


- Legal Periodicals Pre-1990: Older legal periodicals were much more difficult to locate online. Of 107 total, Westlaw and LEXIS had only $26(24 \%)$. None of the remaining 81 resources cited could be located on another database or the World Wide Web. ${ }^{2}$
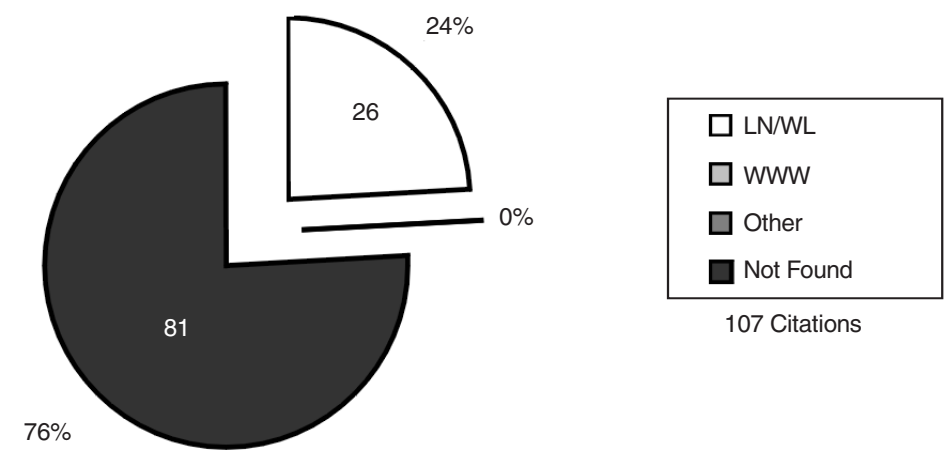

- Non-Legal Periodicals 1990-Present: Full-text versions of roughly two-thirds $(67 \%)$ of the recent non-legal periodicals were located online. In this category, 80 of the 169 citations $(47 \%)$ were available on LEXIS or Westlaw, and 34 more (20\%) were found on other databases, such as JSTOR. ${ }^{3}$

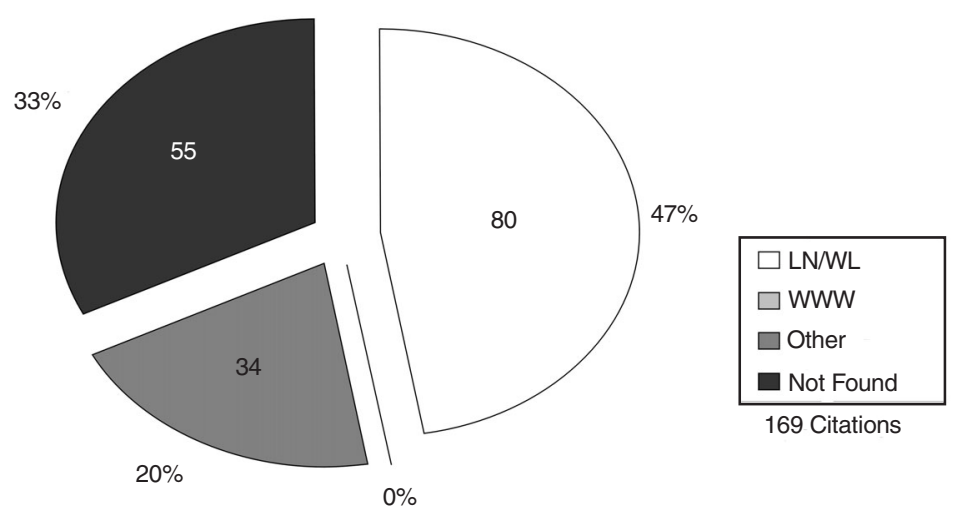


- Non-Legal Periodicals Pre-1990: Of the 16 citations to older non-legal periodicals, none were available on LEXIS or Westlaw. Half (8) were accessible through other databases, and half could not be found.

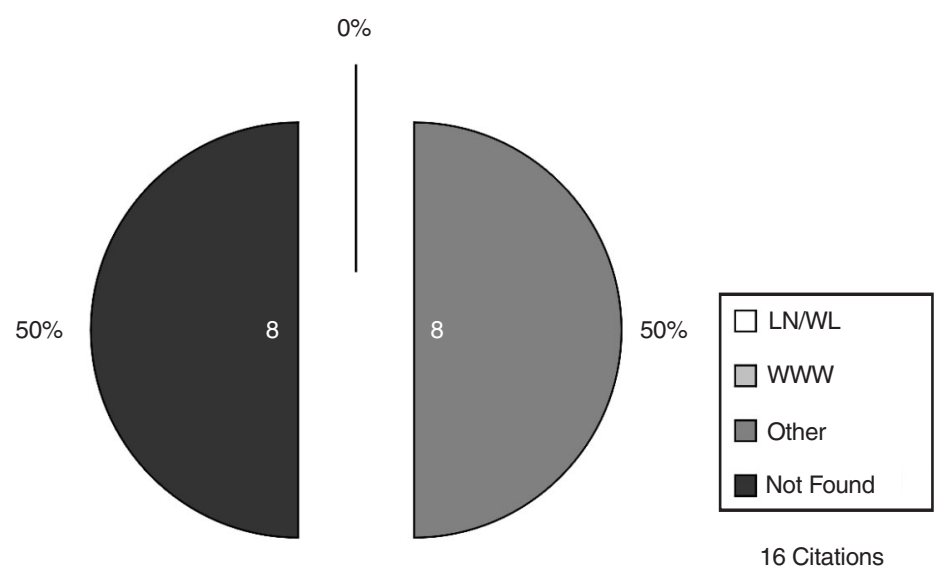

- Books: Books is the major category with the lowest online coverage rate. LEXIS and Westlaw contain the text of some important treatises and looseleaf services, but the vast majority of monographic works, legal or non-legal, are not reproduced online.

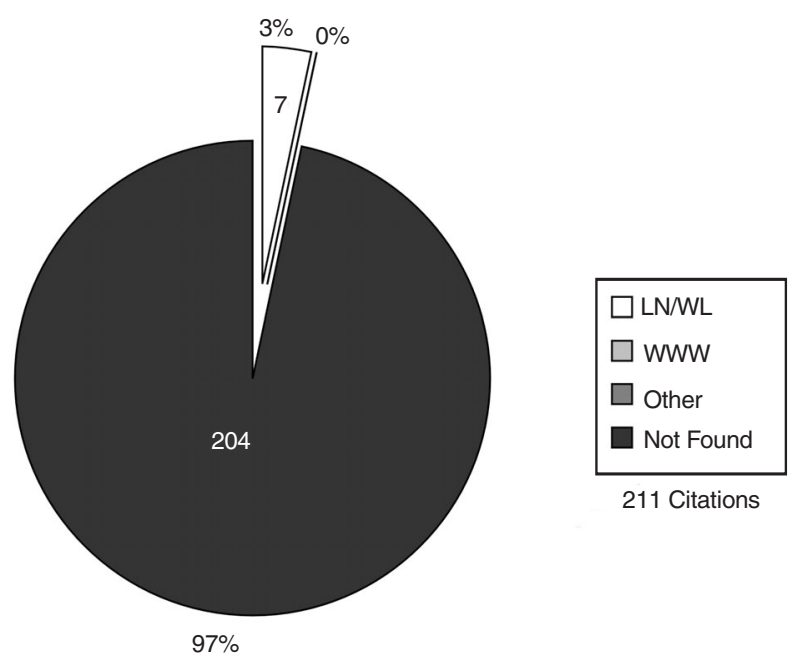


- Reports/Working Papers: Three of the seven articles reviewed cited frequently to various types of reports and working papers. When available online, most of these documents reside on the Internet.

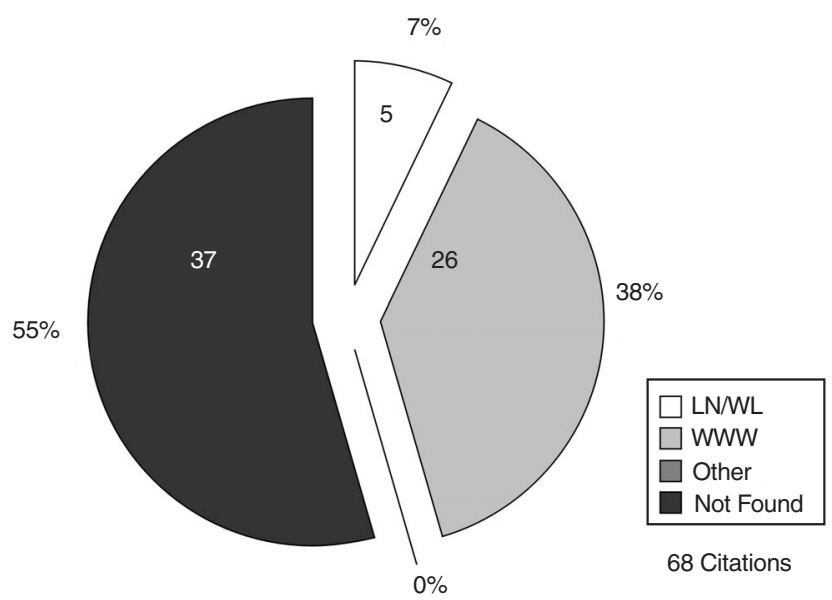

- Federal Cases: With 844 footnote references, federal cases were the most heavily cited category of material in the seven articles. LEXIS and Westlaw provided access to every cited case.

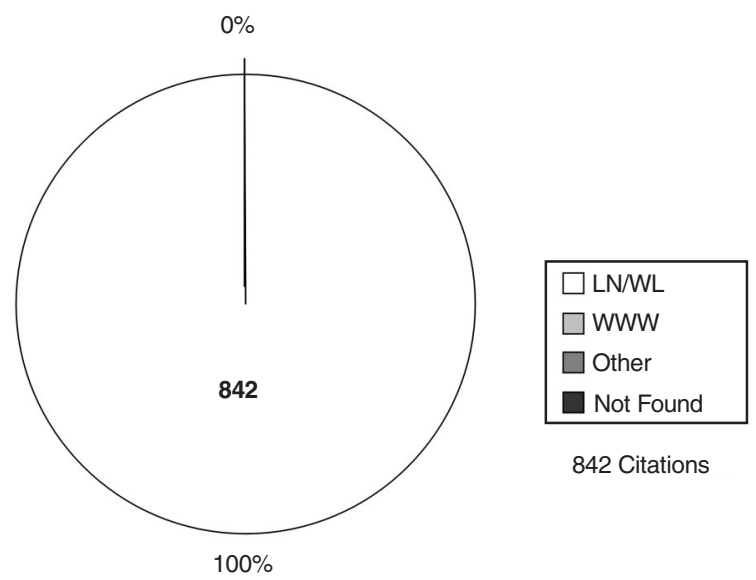


- State Cases: LEXIS and Westlaw provided access to each of the 214 state cases cited.

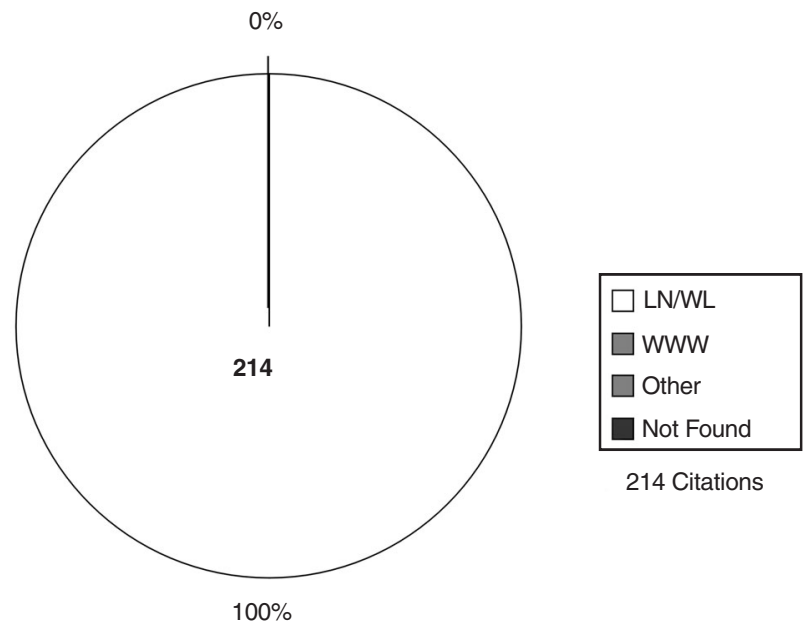

- Federal Law: Almost all U.S. statutory and administrative material is available on LEXIS and Westlaw. Some superseded material could not be found.

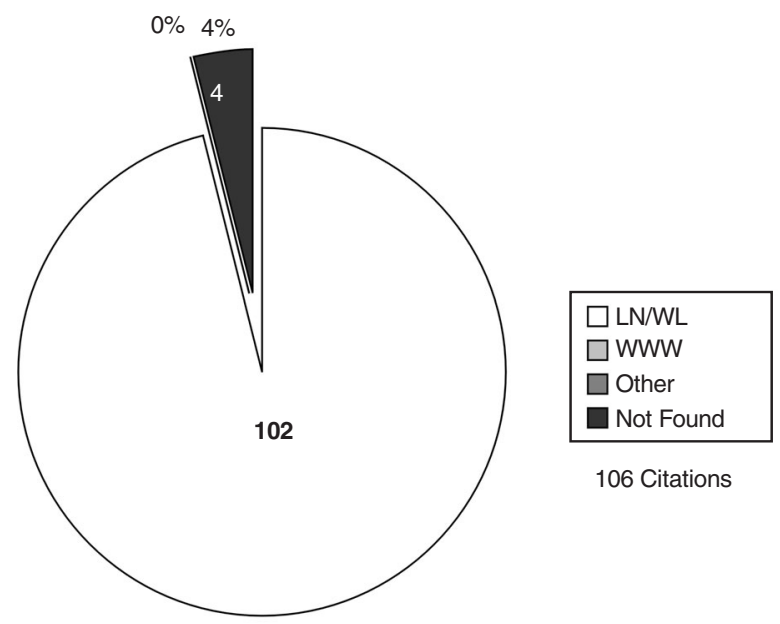


- State Law: The seven articles reviewed only cited to state statutory or regulatory material six times. All were found on LEXIS or Westlaw.

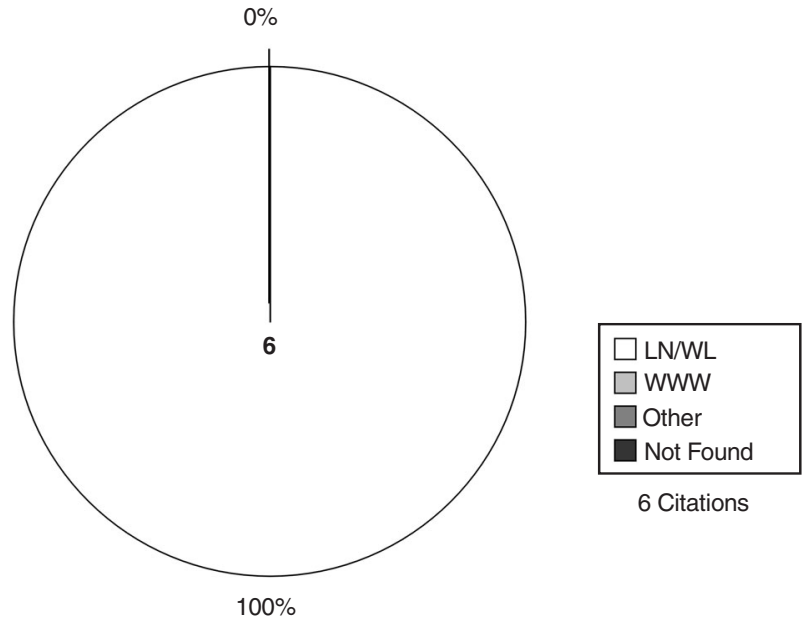

- Uniform Laws: Uniform Laws, Model Codes, and Restatements were cited 12 times. All 12 are available on LEXIS or Westlaw.

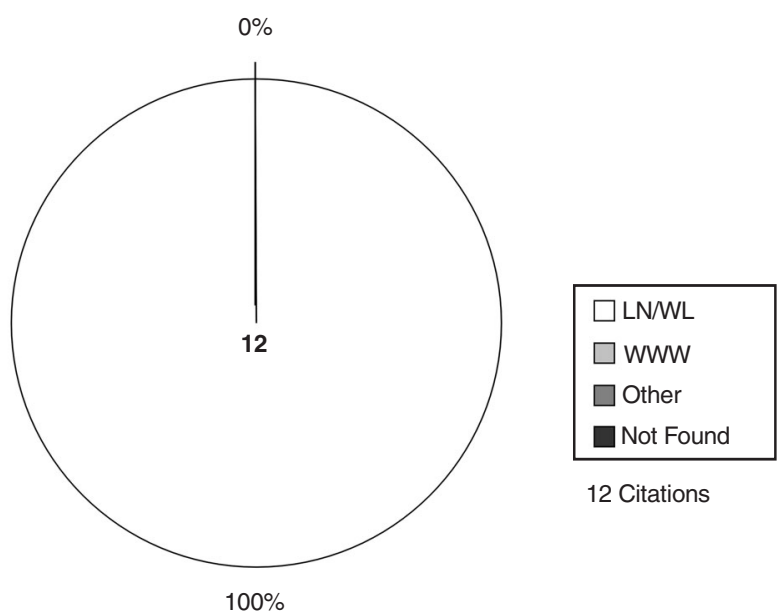


- Foreign Law: Nearly three quarters of the foreign legal material cited in the seven articles could not be found online. Most of the available material was on the World Wide Web rather than LEXIS or Westlaw.

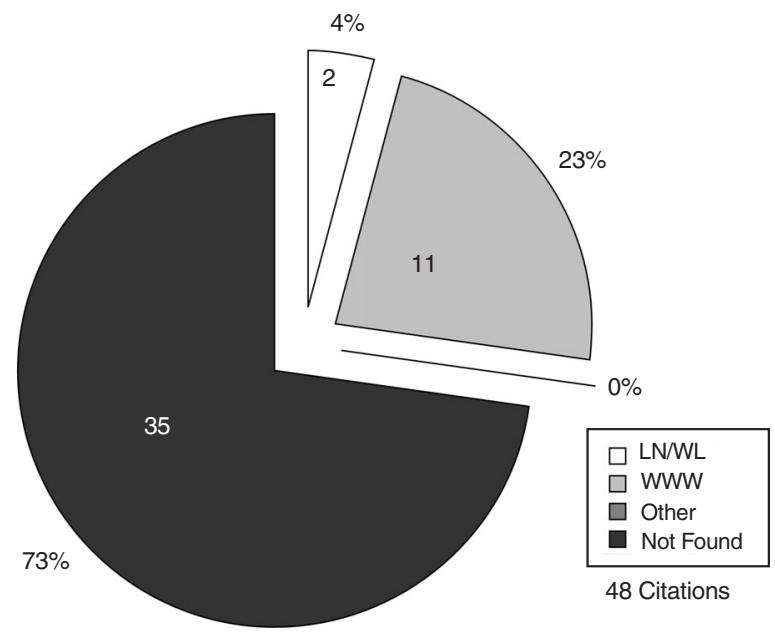

- Court Filings/Transcripts: Pleadings, motions, and trial transcripts were cited frequently in one article (Boese \& Mcclain). None of the 20 cited items could be found online.

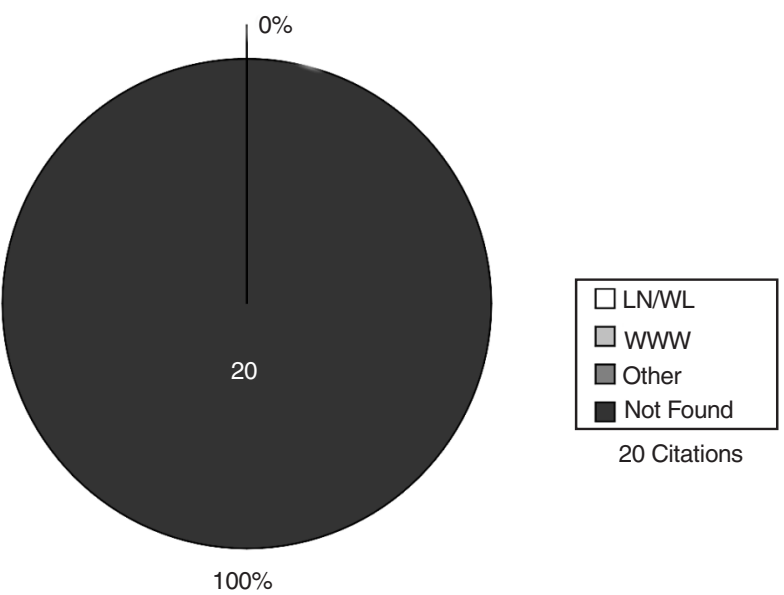




\section{CONCLUSIONS}

Online databases are rich resources for the full-text of certain types of documents cited in recent law review articles. For instance, LEXIS and Westlaw covered over $95 \%(1,166$ out of 1,222$)$ of citations to primary legal materials. The figure jumps to $99 \%(1,164$ out of 1,174$)$, when limited to United States law.

As expected, LEXIS and Westlaw are much less effective for retrieving secondary sources. Only 37\% (280 out of 766) of cited legal and non-legal secondary material could be found. When combined with other databases available at Columbia University, and the Internet, the total jumps to nearly 50\% (380 out of 766). The World Wide Web offered reasonably good access to government documents, working papers, and reports. Other databases covered many non-legal publications.

The fact that $77 \%$ of cited resources were found in electronic form shows how vast the universe of online fulltext materials has become. Yet it also illustrates the opportunity for improvement. Many law review articles cite to books of all kinds, yet precious few can be located outside of print. ${ }^{4}$ In addition, LEXIS and Westlaw's coverage gets thinner as sought-after material gets older. Databases will never solve the research needs of individuals engaged in legal scholarship unless they extend their reach back in time.

Nevertheless, for a number of reasons it seems clear that the percentage of cited works available electronically in fulltext will increase. First, an enormous amount of new material is uploaded every year. ${ }^{5}$ And as search engine technology improves, we will be better able to find the information that has been posted. ${ }^{6}$ Second, in recent years there has been an emergence of interest in making electronic versions of significant historical documentation available. Hein-On-Line, ${ }^{7}, \mathrm{JSTOR},{ }^{8}$ Early English Books Online, ${ }^{9}$ and American Memory ${ }^{10}$ are significant examples of efforts to provide access to older works.

Third, authors tend to cite to recent publications. Of the periodicals cited in the articles examined by this study, for instance, $73 \%$ (332 out of 455 ) were written in the $1990 \mathrm{~s}$. We also know that recently released articles are much more readily available electronically. With authors increasingly referencing new publications with electronic outlets, it seems likely that the percentage of cited works available online will increase.

Finally, it's becoming clear that works get read and cited because they are available online. Students who grew up with the Internet will use available electronic resources and avoid print. ${ }^{11}$ Right or wrong, many people believe they can find everything they need online. And as materials that are easily findable online get cited more and more often, authors will feel pressured to publish with journals that provide electronic access. Otherwise their articles may never be read. 


\section{NOTES}

1. Originally, it was intended that each cited work would be searched only once, and all "id" and "supra" references would be ignored. However, problems with statutes made this unrealistic. Here is a hypothetical set of footnotes that illustrates the problem:

1. 42 U.S.C. $\$ 1015$ (1994).

2. Id. $\S 1015(\mathrm{~g})$.

3. Id. $\S 1015(\mathrm{~b})-(\mathrm{h})$.

4. Id. §§ 1014-1018.

The last footnote covers the first three, and the first footnote covers the second and third. So it was unclear how many discrete sources would result from this list. Rather than create an arbitrary rule for dealing with such situations, it made more sense to count each citation once, even if that source had been cited before.

2. Note that these results were tabulated before Hein-On-Line became available at Columbia University. At this writing, Hein-On-Line offers scanned images of over 150 legal journals beginning with their earliest issues, and will include 3.5 million pages by the end of 2001. See http://heinonline.org/HeinDocs/Overview.htm.

3 . The results here depend on the databases to which Columbia University subscribed at the time the study was undertaken. More of these materials may be on OCLS FirstSearch or Ebsco, for instance, but those are not available on campus. The results are still valid in the sense that few people will have access to every full text database.

4. It remains to be seen whether E-Books will make a significant change in this regard. See generally Lucia Snowhill, E-Books and Their Future in Academic Libraries: An Overview, D-Lib Mag. (July/Aug. 2001), at http://www.dlib.org/dlib/july01/snowhill/ 07snowhill.html; Mick O'Leary, Ebook Scenarios, Online, at 62 (Jan./Feb. 2001).

5. See Michael K. Bergman, The Deep Web: Surfacing Hidden Value (2001), available at http://www.brightplanet.com/deepcontent/tutorials/DeepWeb/deepwebwhitepaper.pdf. Bergman measured the accessibility of "deep Web" sources, which feature searchable databases responsive to direct requests. The study concluded that the "deep Web is the largest growing category of new information on the internet."

6. See id.

7. http://heinonline.org/.

8. http://www.jstor.org/. JSTOR is a searchable archive of over 250 prominent journals in various fields. Every article is presented in PDF format, and therefore retains the authority that comes with original pagination.

9. http://wwwlib.umi.com/eebo. Early English Books Online features images of over 125,000 books published before 1700 .

10. http://memory.loc.gov/ammem/. American Memory is a significant piece of the Library of Congress' National Digital Library Program, an effort to make electronically available materials important in American history. One small subset of American Memory is A Century of Lawmaking, http://memory.loc.gov/ammem/amlaw/lawhome.html, which contains scanned images of Congressional documents from 1774-1873.

11. See Philip M. Davis \& Suzanne A. Cohen, The Effect of the Web on Undergraduate Citation Behavior 1996-1999, 52 JASIS 309, 311 (2001) (finding that as Web use among students increased, the proportion of bibliography citations to books decreased from $30 \%$ to $19 \%$ ). 